\title{
Latihan bodyweight dengan total-body resistance exercise (TRX) dapat meningkatkan kekuatan otot
}

\author{
Ahmad Nasrulloh *, Iswadi Sigit Wicaksono \\ Program Studi Ilmu keolahragaan, Fakultas Ilmu Keolahragaan, Universitas Negeri Yogyakarta. \\ Jalan Colombo No. 1, Karangmalang, Yogyakarta, 55281 Indonesia. \\ * Corresponding Author. Email: ahmadnasrulloh@uny.ac.id
}

Received: 15 April 2020; Revised: 10 May 2020; Accepted: 15 May 2020

\begin{abstract}
Abstrak: Penelitian ini bertujuan untuk mengetahui pengaruh latihan bodyweight dengan Total-body Resistance Exercise (TRX) terhadap peningkatan kekuatan otot. Penelitian ini menggunakan metode penelitian eksperimen. Desain penelitian dalam penelitian ini adalah menggunakan one-group pre-test-post-test design. Subjek dalam penelitian ini adalah members the Fitlab Hotel Tara. Instrumen yang digunakan leg and back dynamometer untuk mengukur kekuatan otot tungkai dan punggung, hand grip dynamometer untuk mengukur kekuatan otot tangan, dan pull and push dynamometer untuk mengukur kekuatan menarik dan mendorong otot lengan. Teknik analisis data menggunakan uji hipotesis dengan analisis uji t (paired sample t test). Hasil penelitian diperoleh persentase peningkatan pada kekuatan otot tungkai sebesar $6,88 \%$, persentase peningkatan pada kekuatan otot punggung sebesar $10,17 \%$, persentase peningkatan pada kekuatan otot tangan sebesar 10,4\%, persentase peningkatan pada kekuatan menarik otot lengan sebesar $8,67 \%$, persentase peningkatan pada kekuatan mendorong otot lengan sebesar $11,26 \%$. Dengan demikian disimpulkan ada pengaruh yang signifikan latihan bodyweight dengan total-body resistance exercise (TRX) terhadap peningkatan kekuatan otot yang meliputi peningkatan kekuata otot tungkai, kekuatan otot punggung, kekuatan otot tangan, kekuatan menarik otot lengan, dan kekuatan mendorong otot lengan.
\end{abstract}

Kata Kunci: Latihan Bodyweight, Total-body Resistance Training, Kekuatan Otot

\section{The bodyweight training with total-body resistance exercise (TRX) can be improving of muscle strength}

\begin{abstract}
This research aims to determine the effect of bodyweight training with Total-body Resistance Exercise (TRX) to the Improvement of Muscle Strength This research used experimental research methods. The research design in this study was using one-group pre-test-post-test design. The subject of the study is members of The Fitlab Tara Hotel. The instruments that have been used are leg and back dynamometer for measure the leg and back muscle strength, hand grip dynamometer for measure the hand muscle strength, and pull and push dynamometer for measure the pulling and pushing arm muscle strength. Data analysis techniques used hypothesis testing with t test analysis (paired sample t test). Based on the results of the study obtained, the percentage increase in leg muscle strength is $6.88 \%$, the percentage increase in back muscle strength is $10.17 \%$, the percentage increase in the hand muscle Strength is $10.4 \%$, the percentage increase in the strength of pulling arm muscles is $8,67 \%$, the percentage increase in the strength of pushing arm muscles is $11.26 \%$. Thus, it was concluded that there was a significant effect of bodyweight training with total-body resistance exercise (TRX) on increasing muscle strength including increased strength of leg muscles, strength of back muscles, strength of hand muscles, strength of pulling arm muscles, and strength of pushing arm muscles.
\end{abstract}

Keywords: Bodyweight Exercise, Total-body Resistance Training, Muscle Strength

How to Cite: Nasrulloh, A., \& Wicaksono, I. (2020). Latihan bodyweight dengan total-body resistance exercise (TRX) dapat meningkatkan kekuatan otot. Jurnal Keolahragaan, 8(1), 5262. doi:https://doi.org/10.21831/jk.v8i1.31208

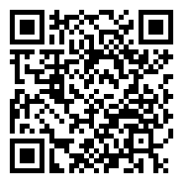

\section{PENDAHULUAN}

Pada era modern seperti ini semua pekerjaan manusia menjadi semakin mudah dan praktis. Manusia diuntungkan untuk dapat dengan mudah dalam memenuhi kebutuhan pekerjaan sehari-hari, 
misalnya: berangkat bekerja dengan kendaraan bermotor, membeli makanan cukup dengan aplikasi yang bias cash of delivery, dan lain sebagainya. Pergeseran pola hidup dari bekerja aktif menjadi pasif ini dapat menjadi pemicu menurunnya tingkat kebugaran jasmani seseorang, sehingga menyebabkan menurunnya kesehatan, mudah lelah, munculnya penyakit degeneratif, yang dampaknya mengurangi produktivitas dalam bekerja. Kebugaran jasmani adalah kemampuan seorang individu untuk memenuhi kebutuhan biasa serta tuntutan yang tidak biasa dalam kehidupan sehari-hari yang dilakukan secara efektif tanpa merasa terlalu lelah dan masih memiliki energi yang tersisa untuk kegiatan bersantai dan rekreasi (Hoeger et al., 2018, p. 19). Nasrulloh (2016, p. 16) mengatakan bahwa kebugaran jasmani merupakan kemampuan seorang individu untuk melakukan aktivitas fisik dalam kehidupan sehari-hari dengan tidak mengalami kelelahan yang berlebihan, sehingga masih memiliki tenaga atau energi untuk mengisi waktu luangnya dengan bersantai dan masih mampu melakukan pekerjaan darurat yang bersifat mendadak. Sehingga praktis dapat dikatakan bahwa setiap orang harus memiliki kebugaran jasmani yang baik agar mampu melakukan aktivitas yang produktif dalam kehidupan sehari-hari.

Kebugaran jasmani terdiri dari dua komponen, yaitu kebugaran yang berhubungan kesehatan dan kebugaran yang berhubungan keterampilan. Senada dengan pendapat American College of Sports Medicine (2013) bahwa definisi kebugaran jasmani yang ditawarkan oleh Pusat Pengendalian dan Pencegahan Penyakit United State berfokus pada perbedaan antara kebugaran jasmani yang berhubungan dengan kesehatan dan kebugaran jasmani berhubungan dengan keterampilan. Kebugaran jasmani diklasifikasikan menjadi dua komponen yaitu kebugaran komponen kesehatan dan kebugaran komponen keterampilan (Ismoko, 2017; Sukamti et al., 2016). Kebugaran yang berhubungan kesehatan terdiri atas daya tahan jantung-paru, daya tahan otot, kekuatan otot, kelentukan, dan komposisi tubuh. Sedangkan kebugaran jasmani yang berhubungan keterampilan terdiri atas kelincahan, keseimbangan, koordinasi, power, waktu reaksi, dan kecepatan. Dengan terpenuhinya komponen kebugaran tersebut, tubuh yang kuat dan sehat akan dicapai. Namun banyak orang yang kesulitan menjadikan tubuhnya bugar dengan alasan terlalu sibuk, sehingga waktu untuk berolahraga tidak ada.

Saat ini olahraga tidak harus dilakukan di tempat terbuka seperti lapangan melainkan dapat dilakukan di dalam ruangan seperti pada pusat kebugaran. Bagi masyarakat kota yang memiliki jadwal padat dengan terbatasnya waktu luang yang dimiliki, berolahraga di pusat kebugaran dapat menjadi solusi yang tepat karena pusat kebugaran beroperasi dari pagi hingga malam sehingga dapat menyesuaikan latihan dengan waktu luang yang dimiliki. Pada umumnya di pusat-pusat kebugaran latihan yang dilakukan adalah latihan dengan sistem pembebanan atau sering disebut dengan latihan beban. Untuk melakukan latihan beban tidak terbatas hanya menggunakan mesin, namun juga dapat menggunakan latihan beban dalam.

Latihan beban merupakan salah satu pilihan tepat untuk membantu meningkatkan kebugaran otot. Berolahraga dengan latihan beban (weight training) baik beban dalam maupun beban luar merupakan latihan yang dilakukan secara sistematis, dengan menggunakan beban sebagai alat untuk menambah kekuatan fungsi otot, guna mencapai tujuan seperti memperbaiki kondisi fisik, mencegah terjadinya cedera, atau untuk tujuan kesehatan. Seperti halnya dikatakan oleh Nasrulloh et al. (2018, p. 4) Latihan beban adalah jenis olahraga umum untuk mengembangkan kekuatan yang menggunakan gaya berat gravitasi, untuk menentang gaya yang dihasilkan oleh otot melalui kontraksi konsentris atau eksentrik. Salah satu komponen kebugaran jasmani yaitu kekuatan otot. Kekuatan otot adalah kemampuan sekelompok otot untuk melawan beban dalam satu usaha (Suharjana, 2013). Kekuatan otot yang dapat dilatih diantaranya otot tungkai, punggung, lengan, dan tangan yang memiliki peran penting dalam menunjang aktivitas sehari-sehari. Sebagai contoh berjalan, mengangkat barang, berolahraga, dan lain sebagainya. Kekuatan otot yang lemah dapat menimbulkan berbagai permasalahan seperti rawan terjadi cidera, mudah lelah, postur tubuh yang jelek dan lain sebagainya.

Latihan kekuatan otot perlu dilakukan oleh seseorang agar dapat membantu dalam melakukan aktivitas sehari-hari seperti mengangkat beban yang berat, menendang atau memukul untuk melindungi diri, dan juga memegang peranan penting dalam pencegahan cidera. Bahkan ada penelitian yang menyebutkan bahwa ada interaksi yang signifikan antara metode latihan beban dan kekuatan otot pada hasil hipertrofi otot (Sucipto \& Widiyanto, 2016). Dengan kata lain bahwa untuk mendapatkan penambahan massa otot juga dapat dilakukan dengan latihan beban kombinasi latihan kekuatan.

Latihan kekuatan otot dapat dilakukan dengan latihan beban. Winters-Stone et al. (2012) mengatakan bahwa wanita yang menghadiri $50 \%$ atau lebih dari sesi pelatihan resistensi yang terprogram memiliki perubahan signifikan yang lebih baik dalam ukuran kekuatan maksimal dibandingkan 
dengan wanita yang kurang patuh, sehingga dapat dikatakan dampak positif resistensi lebih baik daripada peregangan pada peningkatan kekuatan otot maksimal dan kepatuhan latihan berkontribusi pada tingkat peningkatan. Hal senada juga disampaikan Prasetyo dan Nasrulloh (2017) yang menemukan bahwa latihan beban dapat meningkatkan kekuatan otot. Peningkatan tersebut terlihat pada peningkatan persentase kekuatan otot tungkai meningkat 7,43\%, kekuatan otot punggung sebesar $22,15 \%$, kekuatan genggaman kanan $41,42 \%$, kekuatan genggaman kiri 10,67\%, tarikan sama dengan $8,15 \%$ dan kekuatan dorong $11,14 \%$. Latihan kekuatan otot pada umumnya dilakukan dengan menggunakan beban luar seperti menggunakan gym machines ataupun free weight yang dilakukan secara terus-menerus sehingga menimbulkan rasa bosan saat berlatih. Salah satu bentuk model latihan yang sedang berkembang saat ini adalah latihan yang dilakukan dengan bantuan alat berupa TRX (Total-body Resistance Exercise). Variasi latihan dengan bantuan alat TRX ini mampu membantu seseorang untuk melakukan variasi latihan kekuatan untuk mengatasi kebosanan saat menggunakan gym machines ataupun free weight. TRX suspension merupakan alat bantu latihan menggunakan tali sebagai medianya dengan beban tubuh sediri sebagai bebannya. TRX suspension dikembangkan oleh mantan anggota Navy Seal bernama Randy Hetrick sebagai alat bantu bagi para tentara untuk berlatih agar tetap bugar selama bertugas.

Vanagosi (2014, p. 24) mengatakan bahwa latihan TRX merupakan salah satu latihan fisik yang dapat menjaga dan meningkatkan kekuatan, daya tahan otot, keseimbangan, stability, meningkatkan koordinasi otot dan sekaligus melatih otot inti (core) (Vanagosi, 2014, 2015). Lestari dan Nasrulloh (2018) dalam penelitiannya membuktikan bahwa latihan beban body weight training menggunkan resistance band lebih efektif dari pada tanpa resistance band terhadap penurunan berat badan dan persentase lemak pada sampel penelitian. Sedangkan Wibowo dan Fathir (2017) menemukan dalam penelitiannya bahwa latihan dengan Total Body-weight Resistance Exercise (TRX) dapat meningkatkan secara signifikan power otot lengan. Permasalahannya di lapangan masih belum banyak orang yang mengetahui keunggulan dan manfaat latihan menggunakan TRX serta cara latihan dengan TRX dengan baik dan benar. Sejauh ini belum dapat diketahui secara pasti mengenai pengaruh latihan bodyweight dengan Total-body Resistance Exercise (TRX) terhadap peningkatan kekuatan otot. Kondisi inilah kemudian yang mendorong peneliti untuk melakukan penelitian terkait manfaat latihan menggunakan Total-body Resistance Exercise (TRX) suspension terhadap peningkatan kekuatan otot.

\section{METODE}

Penelitian ini menggunakan metode eksperimen. Dengan desain penelitian menggunakan onegroup pre-test - post-test design yaitu eksperimen yang dilaksakan pada satu kelompok saja tanpa kelompok pembanding (Arikunto, 2010, p. 212). Desain tersebut dapat dijelaskan bahwa subjek eksperimen diberikan pre-test dengan mengukur kekuatan otot meliputi tungkai, punggung, lengan, dan tangan. Instrumen yang digunakan adalah menggunakan leg and back dynamometer untuk mengukur kekuatan otot tungkai dan punggung, hand grip dynamometer untuk mengukur kekuatan otot lengan, dan pull and push dynamometer untuk mengukur kekuatan otot tangan dalam menarik dan mendorong. Penelitian hanya dilakukan pada satu kelompok eksperimen yang diberikan perlakuan berupa latihan bodyweight menggunakan TRX. Penelitian ini dilakukan dengan frekuensi tiga kali dalam seminggu, repetisi 4-6 kali, jumlah set 3, recovery 2-5 menit, irama lambat dengan beban sangat berat menggunakan sudut kemiringan 30 derajad sampai dengan 45 derajad. Penelitian ini dilaksanakan di The Fitlab Hotel Tara dan waktu penelitian ini dilaksanakan selama delapan minggu dalam frekuensi latihan adalah tiga kali seminggu, sehingga dapat disimpulkan pelaksanaan perlakuan ini sebanyak dua puluh empat kali tatap muka. Teknik analisis data yang digunakan dalam penelitian ini adalah uji hipotesis dilakukan dengan uji t menggunakan bantuan SPSS 16.0 for Windows Evaluation Version, rumus uji paired sample t-test.

\section{HASIL DAN PEMBAHASAN}

Penelitian ini bertujuan untuk mengetahui pengaruh latihan bodyweight dengan Totalbody Resistance Exercise (TRX) terhadap peningkatan kekuatan otot yang meliputi peningkatan kekuata otot tungkai, kekuatan otot punggung, kekuatan otot tangan, kekuatan menarik otot lengan, dan kekuatan mendorong otot lengan pada members The Fitlab Hotel Tara. Hasil penelitian diperoleh berdasarkan hasil pre-test dan post-test data pengaruh latihan bodyweight dengan Totalbody Resistance Exercise (TRX) terhadap peningkatan kekuatan otot. Hasil dari masing-masing data tersebut diuraikan sebagai berikut: 
Jurnal Keolahragaan 8 (1), 2020 - 55

Ahmad Nasrulloh, Iswadi Sigit Wicaksono

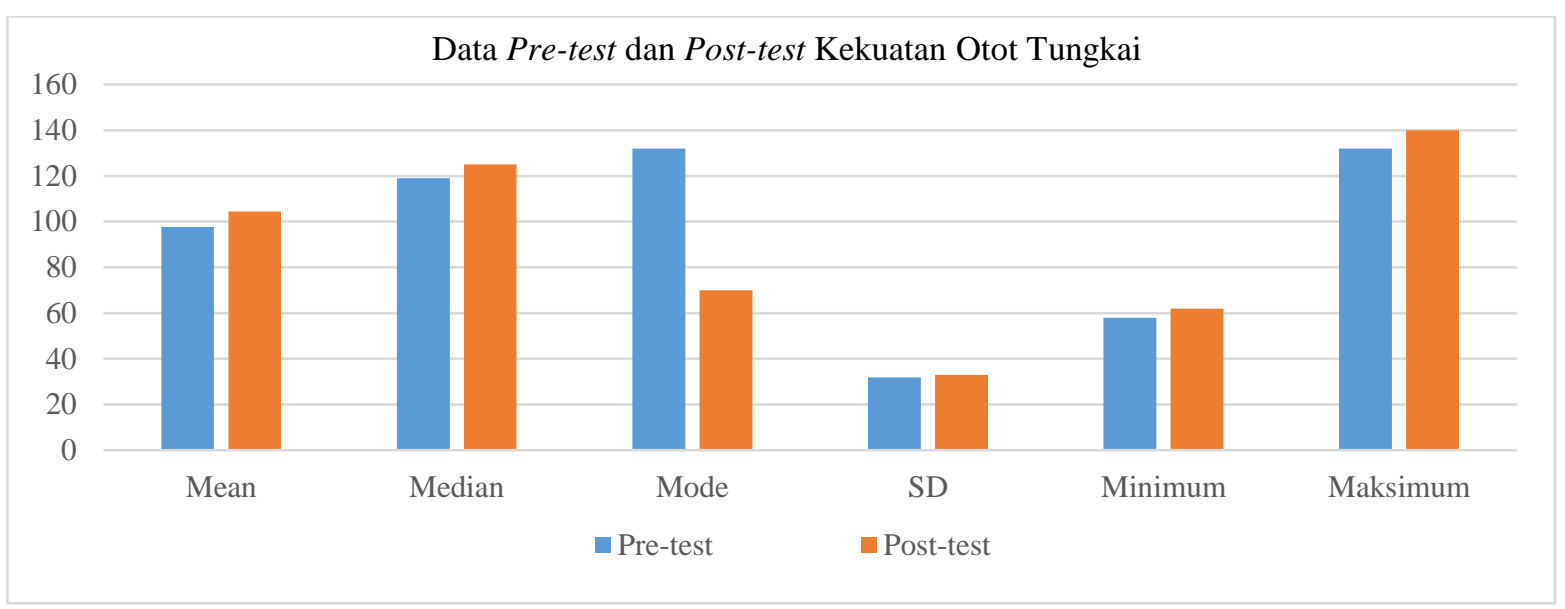

Gambar 1. Diagram Data Kekuatan Otot Tungkai

Dari Gambar 1 dapat diketahui bahwa pada analisis data pre-test menunjukkan mean sebesar 97,73; median sebesar 119; mode 132; standard deviation sebesar 31,92; nilai minimum sebesar 58; dan nilai maksimum sebesar 132, Adapun analisis data post-test menunjukkan mean sebesar 104,45; median sebesar 125; mode 70; standard deviation sebesar 32,87; nilai minimum sebesar 62; dan nilai maksimum sebesar 140 .

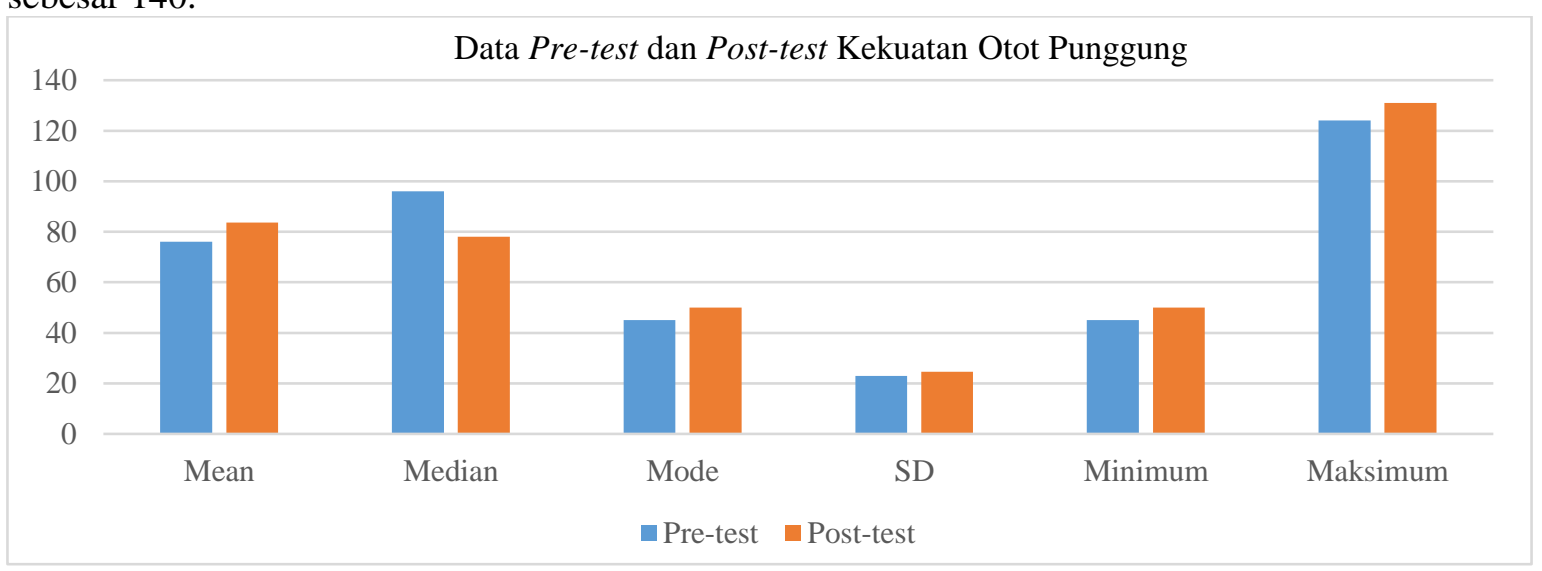

Gambar 2. Diagram Data Kekuatan Otot Punggung

Dari Gambar 2 dapat dilihat bahwa pada analisis data pre-test menunjukkan mean sebesar 76; median sebesar 69; mode 45; standard deviation sebesar 23,03; nilai minimum sebesar 45; dan nilai maksimum sebesar 124, Adapun analisis data post-test menunjukkan mean sebesar 83,73; median sebesar 78; mode 50; standard deviation sebesar 24,58; nilai minimum sebesar 50; dan nilai maksimum sebesar 131.

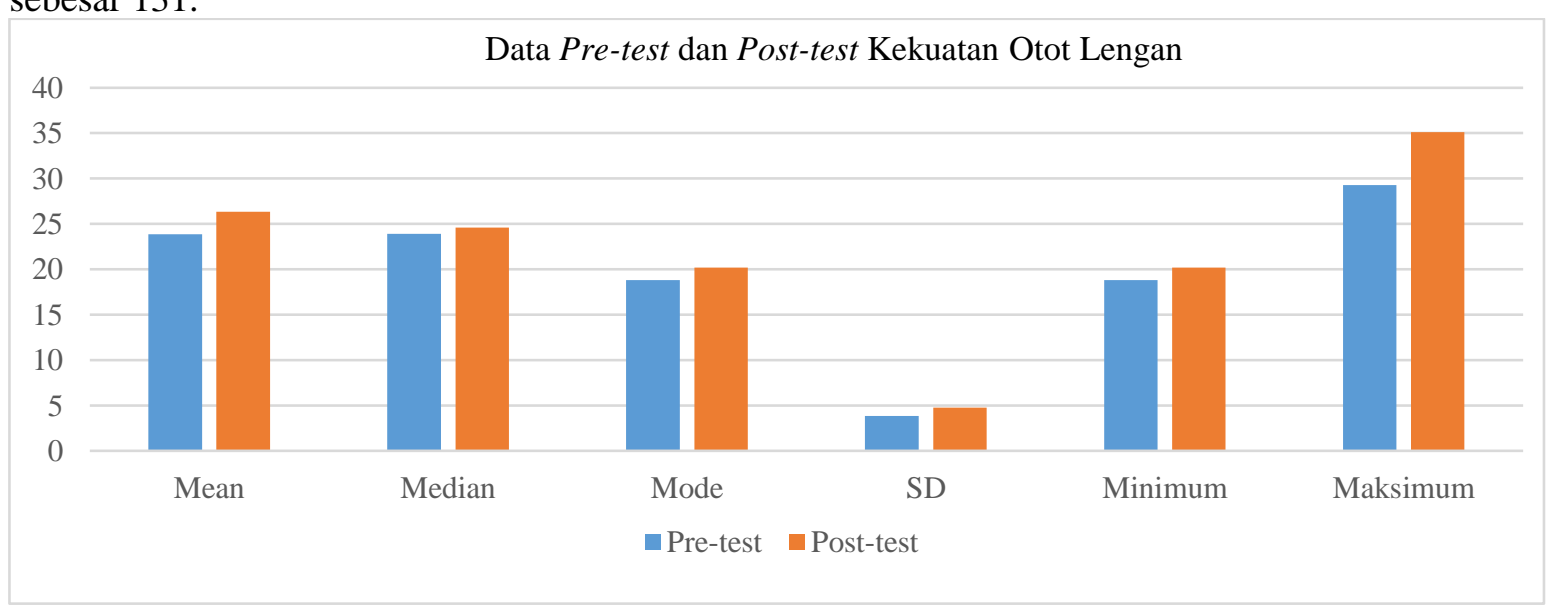

Gambar 3. Diagram data Kekuatan Otot Lengan 
Dari Gambar 3 dapat dilihat bahwa pada analisis data pre-test menunjukkan mean sebesar 23,86; median sebesar 23,9; mode 18,8; standard deviation sebesar 3,85; nilai minimum sebesar 18,8; dan nilai maksimum sebesar 29,3, Adapun analisis data post-test menunjukkan mean sebesar 26,34; median sebesar 24,6; mode 20; standard deviation sebesar 4,75; nilai minimum sebesar 20,20; dan nilai maksimum sebesar 35,1 .

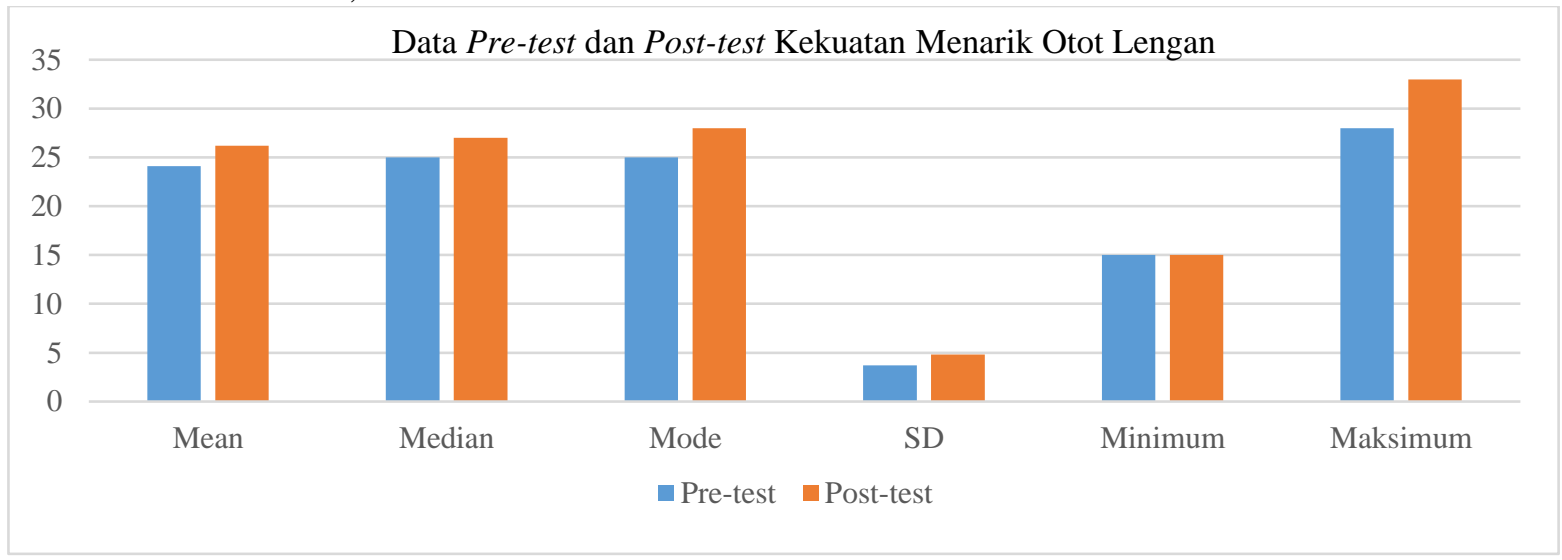

Gambar 4. Diagram Data Kekuatan Menarik Otot Lengan

Dari Gambar 4 dapat dilihat bahwa pada analisis data pre-test menunjukkan mean sebesar 24,09; median sebesar 25; mode 25; standard deviation sebesar 3,70; nilai minimum sebesar 15; dan nilai maksimum sebesar 28, Adapun analisis data post-test menunjukkan mean sebesar 26,18; median sebesar 27; mode 28,; standard deviation sebesar 4,81; nilai minimum sebesar 15; dan nilai maksimum sebesar 33 .

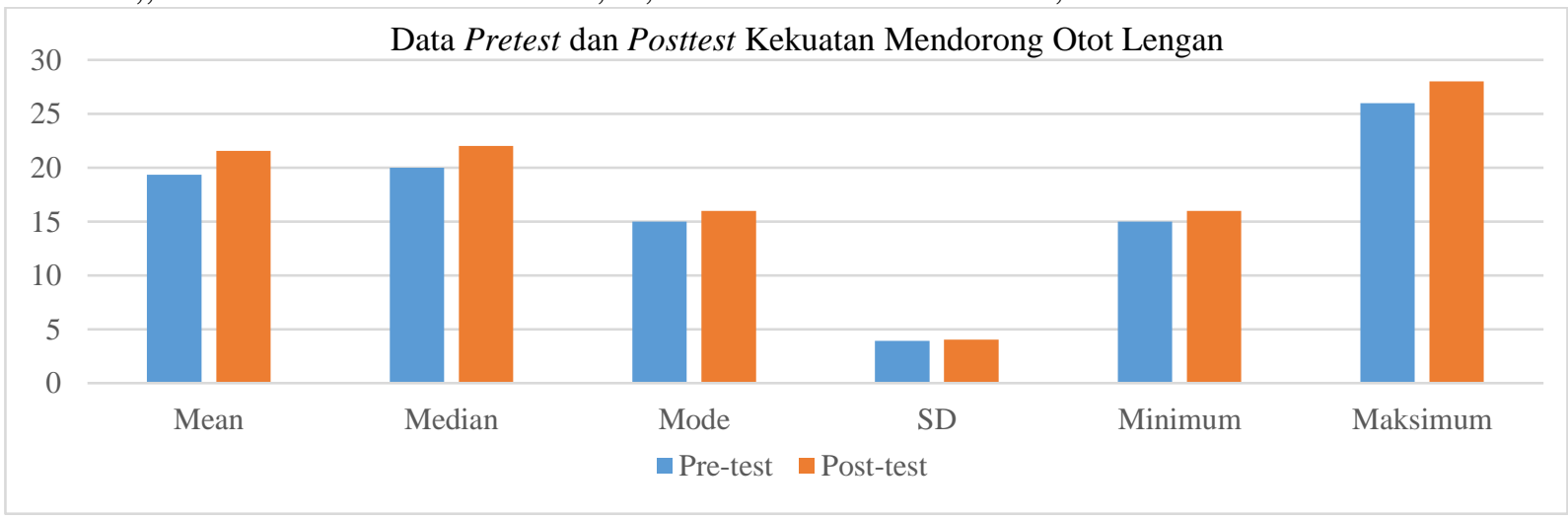

Gambar 5. Diagram data kekuatan mendorong otot lengan

Dari Gambar 5 dapat dilihat bahwa pada analisis data pre-test menunjukkan mean sebesar 19,36; median sebesar 20; mode 15; standard deviation sebesar 3,91; nilai minimum sebesar 15; dan nilai maksimum sebesar 26, Adapun analisis data post-test menunjukkan mean sebesar 16,54; median sebesar 22; mode 16,; standard deviation sebesar 4,05; nilai minimum sebesar 16; dan nilai maksimum sebesar 28 .

Untuk mengetahui besarnya peningkatan kekuatan otot yang meliputi peningkatan kekuata otot tungkai, kekuatan otot punggung, kekuatan otot tangan, kekuatan menarik otot lengan, dan kekuatan mendorong otot lengan pada Members The Fitlab Hotel Tara dengan latihan bodyweight dengan total-body resistance training (TRX) dalam penelitian ini menggunakan dapat dilihat pada Tabel 1.

Tabel 1. Persentase Peningkatan Kekuatan Otot

\begin{tabular}{llcc}
\hline \multicolumn{1}{c}{ Variabel } & Pre-test & Post-test & Persetase peningkatan (\%) \\
\hline Kekuatan Otot Tungkai & 97,73 & 104,45 & 6,88 \\
Kekuatan Otot Punggung & 76 & 83,73 & 10,17 \\
Kekuatan Otot Tangan & 23,86 & 26,35 & 10,40 \\
Kekuatan Menarik Otot Lengan & 24,09 & 26,18 & 8,68 \\
Kekuatan Mendorong Otot Lengan & 19,36 & 21,55 & 11,27 \\
\hline
\end{tabular}

Berdasarkan hasil penelitian pada Tabel 1 diperoleh persentase peningkatan pada kekuatan otot tungkai sebesar $6,88 \%$, persentase peningkatan pada kekuatan otot punggung sebesar $10,17 \%$, persen- 
tase peningkatan pada kekuatan otot tangan sebesar $10,4 \%$, persentase peningkatan pada kekuatan menarik otot lengan sebesar $8,67 \%$, persentase peningkatan pada kekuatan mendorong otot lengan sebesar $11,26 \%$.

Uji normalitas pada penelitian ini digunakan untuk mengetahui mengetahui normal tidaknya suatu sebaran. Uji normalitas dalam penelitian ini menggunakan uji kolmogorov-smirnof Kriteria yang digunakan untuk mengetahui normal tidaknya suatu sebaran adalah jika $\mathrm{p}>0,05(5 \%)$ sebaran dinyatakan normal, dan jika $\mathrm{p}<0,05(5 \%)$ sebaran dikatakan tidak normal. Hasil uji moralitas dapat dilihat pada Tabel 2.

Tabel 2. Hasil Uji Normalitas

\begin{tabular}{llccc}
\hline \multicolumn{1}{c}{ Distribusi Data Variabel } & & $K S$ & $\mathrm{p}$-Value & Kesimpulan \\
\hline Kekuatan otot tungkai & Pre-test & 0,971 & 0,302 & Normal \\
\multirow{3}{*}{ Kekuatan otot punggung } & Post-test & 0,927 & 0,357 & Normal \\
& Pre-test & 0,547 & 0,926 & Normal \\
Kekuatan otot tangan & Post-test & 0,456 & 0,985 & Normal \\
\multirow{2}{*}{ Kekuatan menarik otot lengan } & Pre-test & 0,604 & 0,859 & Normal \\
& Post-test & 0,625 & 0,829 & Normal \\
Kekuatan mendorong otot lengan & Pre-test & 0,774 & 0,587 & Normal \\
& Post-test & 0,475 & 0,978 & Normal \\
& Pre-test & 0,561 & 0,912 & Normal \\
\hline
\end{tabular}

Dari hasil pada Tabel 2, diketahui bahwa keseluruhan $p$ value $>0,05$ yaitu data pre-test kekuatan otot tungkai dengan $\mathrm{p}(0,302)>0,05$, post-test kekuatan otot tungkai dengan $\mathrm{p}(0,302)>0,05$, data pretest kekuatan otot punggung dengan $\mathrm{p}(0,926)>0,05$, post-test kekuatan otot punggung dengan $\mathrm{p}(0,985)$ $>0,05$, data pre-test kekuatan otot tangan dengan $\mathrm{p}(0,859)>0,05$, post-test kekuatan otot tangan dengan $\mathrm{p}(0,829)>0,05$, data pre-test kekuatan menarik otot lengan dengan $\mathrm{p}(0,587)>0,05$, post-test kekuatan menarik otot lengan dengan $\mathrm{p}(0,978)>0,05$, data pre-test kekuatan mendorong otot lengan dengan $\mathrm{p}$ $(0,912)>0,05$, dan post-test kekuatan mendorong otot lengan dengan $\mathrm{p}(0,980)>0,05$. Dapat disimpulkan bahwa tidak ada perbedaan frekuensi observasi (hasil) dengan frekuensi harapan normal, berarti semua data pada penelitian ini berdistribusi normal. Dengan demikian semua data pada penelitian ini memenuhi asumsi normalitas sebaran. Pengujian homogenitas dilakukan dengan bantuan software komputer SPSS. Hasil uji homo-genitas secara ringkas dapat dilihat pada Tabel 3.

Tabel 3. Uji Homogenitas

\begin{tabular}{|c|c|c|}
\hline Variabel & Sig & Kesimpulan \\
\hline Kekuatan otot tungkai & 0,779 & Homogen \\
\hline Kekuatan otot punggung & 0,889 & Homogen \\
\hline Kekuatan otot tangan & 0,490 & Homogen \\
\hline Kekuatan menarik otot lengan & 0,506 & Homogen \\
\hline Kekuatan mendorong otot lengan & 0,864 & Homogen \\
\hline
\end{tabular}

Hasil uji homogenitas menunjukkan bahwa untuk data pre-test dan post-test kekuatan otot tungkai nilai signifikansi lebih besar dari $0,05(0,779>0,05)$, berarti data pre-test dan post-test kekuatan otot tungkai bersifat homogen, data pre-test dan post-test kekuatan otot punggung nilai signifikansi lebih besar dari $0,05(0,889>0,05)$, berarti data pre-test dan post-test kekuatan otot punggung bersifat homogen, data pre-test dan post-test kekuatan otot tangan nilai signifikansi lebih besar dari 0,05 $(0,490>0,05)$, berarti data pre-test dan post-test kekuatan otot tangan bersifat homogen, data pre-test dan post-test kekuatan menarik otot lengan nilai signifikansi lebih besar dari $0,05(0,506>0,05)$, berarti data pre-test dan post-test kekuatan menarik otot lengan bersifat homogen, dan data pre-test dan post-test kekuatan mendorong otot lengan nilai signifikansi lebih besar dari $0,05(0,864>0,05)$, berarti data pre-test dan post-test kekuatan mendorong otot lengan bersifat homogen. Berdasarkan hasil uji homogenitas di atas data-data kekuatan otot pada Members the Fitlab Hotel Tara diperoleh nilai signifikansi lebih besar dari 0,05 , dengan hasil yang diperoleh tersebut dapat disimpulkan bahwa varians bersifat homogen.

Setelah uji data normalitas dan homogenitas, selanjutnya dilakukan pengujian. Pengujian hipotesis dalam penelitian ini yaitu: (1) ada pengaruh latihan bodyweight dengan TRX terhadap peningkatan kekuatan otot tungkai pada members The Fitlab Hotel Tara, (2) ada pengaruh latihan bodyweight dengan 
TRX terhadap peningkatan kekuatan otot punggung pada members The Fitlab Hotel Tara, (3) ada pengaruh latihan bodyweight dengan TRX terhadap peningkatan kekuatan otot tangan pada members The Fitlab Hotel Tara, (4) ada pengaruh latihan bodyweight dengan TRX terhadap peningkatan kekuatan menarik otot lengan pada members The Fitlab Hotel Tara, (5) ada pengaruh latihan bodyweight dengan TRX terhadap peningkatan kekuatan mendorong otot lengan pada members The Fitlab Hotel Tara.

Uji t dalam penelitian ini dimaksudkan untuk menjawab hipotesis yang telah diajukan. Pengujian hipotesis dilakukan untuk mengetahui penerimaan atau penolakan hipotesis yang diajukan. Uji hipotesis menggunakan uji-t (paired sampel t test) pada taraf signifikan 5\%. Hasil uji hipotesis (uji-t) dapat di lihat pada Tabel 4.

Tabel 4. Hasil Uji Hipotesis

\begin{tabular}{lccc}
\hline & Variabel & Sig & Kesimpulan \\
\hline Kekuatan otot tungkai & 0,000 & Signifikan \\
Kekuatan otot punggung & 0,000 & Signifikan \\
Kekuatan otot tangan & 0,000 & Signifikan \\
Kekuatan menarik otot lengan & 0,000 & Signifikan \\
Kekuatan mendorong otot lengan & 0,000 & Signifikan \\
\hline
\end{tabular}

Hasil uji t pada kekuatan otot punggung menunjukkan hasil bahwa nilai p (sig.) sebesar 0,000. Ternyata $\mathrm{p}(0,000)<0,05$; dengan demikian $\mathrm{H}_{\mathrm{o}}$ ditolak dan $\mathrm{H}_{\mathrm{a}}$ diterima; sehingga dapat disimpulkan ada pengaruh latihan bodyweight dengan TRX terhadap peningkatan kekuatan otot punggung. Hasil pengujian hipotesis pada otot tangan menunjukkan bahwa nilai $p$ (sig.) sebesar 0,000 . Ternyata $p(0,000)$ $<0,05$; dengan demikian $\mathrm{H}_{\mathrm{o}}$ ditolak dan $\mathrm{H}_{\mathrm{a}}$ diterima; sehingga dapat disimpulkan ada pengaruh latihan bodyweight dengan TRX terhadap peningkatan kekuatan otot tangan. Hasil pengujian hipotesis pada kekuatan menarik otot lengan diketahui bahwa nilai $\mathrm{p}$ (sig.) sebesar 0,000 . Ternyata $\mathrm{p}(0,000)<0,05$; dengan demikian $\mathrm{H}_{\mathrm{o}}$ ditolak dan $\mathrm{H}_{\mathrm{a}}$ diterima; sehingga dapat disimpulkan ada pengaruh latihan bodyweight dengan TRX terhadap peningkatan kekuatan menarik otot lengan. Sedangkan hasil pengujian hipotesis pada kekuatan mendorong otot lengan diketahui bahwa nilai $\mathrm{p}$ (sig.) sebesar 0,000 . Ternyata $\mathrm{p}(0,000)<0,05$; dengan demikian $\mathrm{H}_{\mathrm{o}}$ ditolak dan $\mathrm{H}_{\mathrm{a}}$ diterima; sehingga dapat disimpulkan ada pengaruh latihan bodyweight dengan TRX terhadap peningkatan kekuatan mendorong otot lengan. Sehingga secara keseluruhan dapat diketahui bahwa nilai $\mathrm{p}$ (sig.) sebesar 0,000 . Ternyata $\mathrm{p}(0,000)<0,05$; dengan demikian $\mathrm{H}_{\mathrm{o}}$ ditolak dan $\mathrm{H}_{\mathrm{a}}$ diterima; sehingga dapat disimpulkan ada pengaruh latihan bodyweight dengan TRX terhadap peningkatan kekuatan otot otot tungkai, punggung, tangan, kekuatan menarik otot lengan dan kekuatan mendorong otot lengan.

Dari tabel hasil pengujian hipotesis di atas dapat diketahui bahwa nilai p (sig.) kekuatan otot tungkai, punggung, tangan, kekuatan menarik otot lengan dan kekuatan mendorong otot lengan menunjukkan hasil sebesar 0,000. Sehingga dengan nilai p $(0,000)<0,05$; dengan demikian Ho ditolak dan Ha diterima; sehingga dapat disimpulkan ada pengaruh latihan bodyweight dengan TRX terhadap peningkatan kekuatan otot yang meliputi peningkatan kekuata otot tungkai, kekuatan otot punggung, kekuatan otot tangan, kekuatan menarik otot lengan, dan kekuatan mendorong otot lengan.

Hasil pengamatan dan wawancara peneliti pada members The Fitlab Hotel bahwa banyak members yang ingin melatih kekuatan otot hanya berfokus pada latihan beban luar seperti menggunakan gym machines ataupun free weight yang dilakukan berulang-ulang sehingga members merasakan kebosanan saat berlatih. Oleh karena itu membutuhkan sebuah metode latihan yang baik dalam meningkatkan kekuatan otot pada tubuh. Selain itu juga diperlikan beberapa variasi latihan agar tidak terjadi kebosanan pada saat melakukan latihan beban.

Kekuatan merupakan salah satu komponen dasar biomotor yang diperlukan dalam setiap olahraga. Selain itu bahwa setiap orang memerlukan kekuatan otot untuk dapat melakukan aktivitas dalam kehidulan sehari-hari supaya lebih efektif. Dimana kekuatan merupakan kemampuan otot atau sekelompok otot untuk menahan atau menerima beban dalam satu kerja.

Berdasarkan hasil analisisi uji t paired sampel t-test kekuatan otot tungkai, punggung, tangan, kekuatan menarik otot lengan dan kekuatan mendorong otot lengan telah diperoleh nilai-nilai $\mathrm{t}_{\text {hitung }}>\mathrm{t}$ tabel, dan nilai $p(0,000)<$ dari 0,05 , hasil tersebut diartikan ada pengaruh latihan bodyweight dengan totalbody resistance exercise (TRX) terhadap peningkatan kekuatan otot yang meliputi peningkatan kekuata otot tungkai, kekuatan otot punggung, kekuatan otot tangan, kekuatan menarik otot lengan, dan kekuatan mendorong otot lengan. Latihan bodyweight dalam penelitian ini memfokuskan latihan pembebanan dengan 
beban menggunakan bantuan alat berupa TRX. TRX suspension merupakan alat bantu latihan pembebanan menggunakan tali sebagai medianya dengan beban dari dalam tubuh sediri sebagai bebannya. Sehingga latihan yang dilakukan dengan menggunakan bantuan TRX tersebut dapat membantu memberikan pembebanan pada otot-otot yang dituju pada tubuh menjadi terbenani dalam melakukan latihan. Semakin sering beban yang diberikan yang meningkat secara progresif maka akan akan semakin dapat meingkatkan kekuatan otot.

Berdasarkan analisis data diketahui bahwa ada pengaruh latihan bodyweight dengan total-body resistance exercise (TRX) terhadap peningkatan kekuatan otot yang meliputi peningkatan pada kekuatan otot tungkai, kekuatan otot punggung, kekuatan otot tangan, kekuatan menarik otot lengan, dan kekuatan mendorong otot lengan. Adapun besaran peningkatanya adalah: (1) kekuatan otot tungkai mengalami peningkatan sebesar 6,88 \%; (2) kekuatan otot punggung meningkat sebesar 10,17\%; (3) kekuatan otot tangan mengalami peningkatan sebesar $10,40 \%$; (4) kekuatan menarik otot lengan mengalami peningkatan 8,68\%; dan (5) kekuatan mendorong otot lengan mengalami peningkatan sebesar $11,27 \%$. Jadi dapat disimpulkan bahwa latihan bodyweight dengan total-body resistance exercise (TRX) dapat memberikan pengaruh yang signifikan terhadap peningkatan kekuatan otot yang meliputi kekuatan otot tungkai, kekuatan otot punggung, kekuatan otot tangan, kekuatan menarik otot lengan, dan kekuatan mendorong otot lengan. Hal ini sependapat Vanagosi (2014, p. 23) yang menyatakan bahwa TRX adalah salah satu latihan tahanan untuk melatih kekuatan, dapat dilakukan dimana saja dan oleh siapa saja dari atlet pemula sampai atlet elit. Dibandingkan dengan pelatihan resistensi pita elastis, TRX-Old Age menginduksi efek serupa pada mobilitas fungsional, kekuatan dan kemampuan keseimbangan orang dewasa yang sehat (Gaedtke \& Morat, 2016). Selain itu Heltne et al. (2014) juga mengungkapkan dalam hasil penelitiannya menunjukkan bahwa pelatihan TRX meningkatkan variabel kebugaran otot pada orang dewasa yang lebih muda dan setengah baya yang umumnya terkait dengan RT.

Keberhasilan ini tidak terlepas dari sebuah program latihan yang dilakukan dengan baik. Program latihan ini dibuat dengan tujuan agar latihan yang dilakukan dapat berjalan dengan terukur dan teratur, sehingga tujuan latihan dapat tercapai secara optimal. Adapun program latihan yang diberikan dalam latihan dengan menggunakan TRX ini dilakukan dengan frekuensi tiga kali dalam seminggu, dengan jumlah repetisi 4-6 kali, jumlah set 3 set, waktu recovery 2-5 menit, irama latihan lambat dengan beban sangat berat menggunakan sudut kemiringan $30^{\circ}$ sampai dengan $45^{\circ}$. Pembebanan akan dilakukan meningkat secara progresif dengan memperkecil sudut kemiringan, karena semakin kecil sudut kemiringannya maka akan semakin berat. Program ini mengacu pada rekomendasi Berget dan KrohnHansen (2013, p. 23) yaitu latihan TRX untuk melatih kekuatan menggunakan jumlah repetisi 4-6 kali dan jumlah setnya 3 set dan menggunakan beban sangat berat. Dalam melakukan latihan beban untuk meningkatkan kekuatan otot perlu memperhatikan intensitas latihan. Intensitas latihan ini akan menunjukkan berat dan ringannya sebuah latihan pembebanan.

Kekuatan otot akan dapat dilatih dengan memperhatikan jumlah set dalam setiap sesi latihan. Arazi dan Asadi (2012) merekomendasikan bahwa, COM (kelompok perlakuan terkondensasi) yaitu dengan melakukan latihan resistensi untuk tiga set secara terus menerus lebih baik untuk meningkatkan kekuatan otot dan kedua program pelatihan ini tepat untuk meningkatkan daya tahan otot. Selain itu juga perlu memperhatikan intensitas latihan agar program latihan kekuatan dapat bermakna. Seperti yang dikatakan oleh Bompa dan Buzzichelli (2015, p. 128) bahwa untuk melatih kekuatan otot maksimal juga perlu memperhatikan intensitas latihan, karena untuk meningkatkan kekuatan otot secara maksimal seharusnya dilakukan dengan intensitas 70\%-80 \% dari 1 RM (Repetisi Maksimal) untuk tingkat medium, 80\%-90\% dari 1 RM (Repetisi Maksimal) untuk tingkat berat, 90\%-100\% dari 1 RM untuk beban maksimal dan di atas $105 \%$ dari $1 \mathrm{RM}$ untuk supermaksimal.

Dalam penelitian ini menggunakan sudut kemiringan $30^{\circ}$ sampai dengan $45^{\circ}$ dari posisi berdiri, dimana subjek bersandar dan memegang pegangan TRX sudut $45^{\circ}$ dengan kaki langsung di bawah titik gantung kemudian menurun secara bertahap menjadi $30^{\circ}$. Persamaan prediksi dihitung untuk setiap sudut berdasarkan pengukuran yang dilakukan pada titik gantung. Ketika sudut dari berdiri meningkat, jumlah perlawanan yang dihadapi meningkat. Hal tersebut senada dengan hasil penelitian (Jay Dawes, 2015) dalam penelitiannya menemukan bahwa rata-rata, subjek mengalami $37,44 \pm 1,45 \%$ dari massa tubuh orangcoba pada $30^{\circ}, 52,88 \pm 0,59 \%$ pada $45^{\circ}, 68,08 \pm 1,95 \%$ pada $60^{\circ}$, dan $79,38 \pm 2,14 \%$ pada $75^{\circ}$ dari vertikal, frek kenaikan $30,5 \mathrm{~cm}$ menjauh dari titik gantung pada resistensi agak bervariasis sehingga dapat disimpulkan bahwa sudut yang menurun menghasilkan peningkatan resistensi massa tubuh selama penggunaan. 
Peningkatan kemampuan kerja otot akibat latihan disebabkan oleh perubahan fisiologis yang terjadi pada sistem neuromuscular (adaptasi sistem neuromuscular). Peningkatan kekuatan otot menyebabkan kontraksi otot lebih kuat (power meningkat), pengulangan kontraksi lebih cepat (meningkatkan kecepatan), dan periode latihan tahan lama (meningkatkan ketahanan otot). Menurut Baechle dan Earle (2019); Suharjana (2013, p. 18), penambahan ukuran otot sering kali disebabkan bertambahnya serat-serat otot yang ada, serat-serat yang memang sudah ada sejak lahir. Bertambahnya serat-serat otot disebabkan bertambahnya protein aktin dan miosin. Besar kecilnya kekuatan otot tergantung besarnya serabut-serabut otot itu sendiri, dan juga tergantung pada jumlah serabut-serabut saraf yang mensuplai serabut otot.

Latihan beban akan meningkatkan protein kontraktil sehingga terjadi peningkatan konsentrasi ATP-PC (adenosin trifosfat-phosphocreatine) dan enzim glikolisis. Menurut Coker (Suharjana, 2013, p. 20), bahwa latihan dapat menyebabkan otot menjadi responsif terhadap beban, pembesaran serabut otot, peningkatan jumlah kapiler, peningkatan jumlah dan ukuran mitokondria, dan peningkatan protein kontraktil. Pendapat yang sama dikatakan Lamb (Suharjana, 2013, p. 20) menyatakan latihan dapat berpengaruh pada hipertrofi otot, ukuran mitokondria, meningkatan ukuran myofibril dan sakoplasmik, meningkatkan konsentrasi ATP-PC dan enzim glikolisis. Dengan terjadinya hipertrofi otot dan membaiknya system saraf, serta meningkatnya protein kontraktil maka akan menyebabkan meningkatnya kekuatan otot. Seperti dinyatakan oleh Bompa dan Haff (2009) bahwa kekuatan otot dipengaruhi oleh penampang lintang atau diameter otot terutama diameter filament myosin, kemampuan rekruitmen serabut otot cepat dan sinkronisasi otot dalam aksi gerak.

\section{SIMPULAN}

Berdasarkan hasil penelitian dan pembahasan sebelumnya diperoleh nilai-nilai $\mathrm{t}_{\text {hitung }}>\mathrm{t}_{\text {tabel }}$, dan nilai $p(0,000)<$ dari 0,05 , hasil tersebut menunjukkan bahwa nilai $\mathrm{t}_{\text {hitung }}$ lebih besar dari pada $\mathrm{t}_{\text {tabel. }}$. Dengan demikian disimpulkan bahwa latihan bodyweight dengan total-body resistance exercise (TRX) dapat memberikan pengaruh yang signifikan terhadap peningkatan kekuatan otot yang meliputi peningkatan kekuata otot tungkai, kekuatan otot punggung, kekuatan otot tangan, kekuatan menarik otot lengan, dan kekuatan mendorong otot lengan. Adapun besaran peningkatanya adalah: (1) kekuatan otot tungkai mengalami peningkatan sebesar 6,88 \%; (2) kekuatan otot punggung meningkat sebesar 10,17 \%; (3) kekuatan otot tangan mengalami peningkatan sebesar 10,40 \%; (4) kekuatan menarik otot lengan mengalami peningkatan 8,68 \%; dan (5) kekuatan mendorong otot lengan mengalami peningkatan sebesar 11,27\%. Jadi dapat disimpulkan bahwa latihan bodyweight dengan total-body resistance exercise (TRX) dapat memberikan pengaruh yang signifikan terhadap peningkatan kekuatan otot yang meliputi kekuatan otot tungkai, kekuatan otot punggung, kekuatan otot tangan, kekuatan menarik otot lengan, dan kekuatan mendorong otot lengan.

\section{DAFTAR PUSTAKA}

American College of Sports Medicine. (2013). ACSM's health-related physical fitness assessment manual. Lippincott Williams \& Wilkins.

Arazi, H., \& Asadi, A. (2012). Multiple sets resistance training: Effects of Condensed versus circuit models on muscular strength, endurance and body composition. Journal of Human Sport and Exercise, 7(4), 733-740. https://doi.org/10.4100/jhse.2012.74.01

Arikunto, S. (2010). Prosedur penelitian: Suatu pendekatan praktik. Rineka Cipta.

Baechle, T. R., \& Earle, R. W. (2019). Weight training: Steps to success. Human Kinetics.

Berget, A., \& Krohn-Hansen, L. (2013). Sling training: full body suspension workout. Meyer \& Meyer Fachverlag und Buchhandel GmbH.

Bompa, T. O., \& Buzzichelli, C. (2015). Periodization training for sports. Human kinetics.

Bompa, T. O., \& Haff, G. (2009). Periodization: Theory and methodology of training. Human Kinetics.

Gaedtke, A., \& Morat, T. (2016). Effects of Two 12-week Strengthening Programmes on Functional Mobility, Strength and Balance of Older Adults: Comparison between TRX Suspension Training versus an Elastic Band Resistance Training. Central European Journal of Sport Sciences and Medicine. https://doi.org/10.18276/cej.2016.1-05 
Heltne, T., Janot, J., Welles, C., Riedel, J., Anderson, H., Howard, A., \& Myhre, S. L. (2014). Effects of TRX versus Traditional Resistance Training Programs on Measures of Muscular Performance in Adults. Medicine \& Science in Sports \& Exercise. https://doi.org/10.1249/01.mss.0000493944.82425.a8

Hoeger, W. W. K., Hoeger, S. A., Hoeger, C. I., \& Fawson, A. L. (2018). Lifetime physical fitness and wellness. Cengage Learning.

Ismoko, A. P. (2017). Tingkat kebugaran aerobik atlet bola voli Yunior Sleman United Volleyball Club. Jurnal Pendidikan Jasmani Dan Keolahragaan, 1(1), 42-49.

Jay Dawes, D. M. (2015). Resistance Characteristics of the TRX ${ }^{\mathrm{TM}}$ Suspension Training System at Different Angles and Distances from the Hanging Point. Journal of Athletic Enhancement. https://doi.org/10.4172/2324-9080.1000184

Lestari, A., \& Nasrulloh, A. (2018). Efektivitas latihan body weight training dengan dan tanpa menggunakan resistance band terhadap penurunan berat badan dan persentase lemak. MEDIKORA, 17(2), 91-101. https://doi.org/10.21831/medikora.v17i2.29180

Nasrulloh, A. (2016). Pengaruh metode latihan super set dan compound set dengan istirahat antar set 30 dan 120 detik terhadap kebugaran komponen kesehatan. Universitas Negeri Surabaya.

Nasrulloh, A., Prasetyo, Y., \& Apriyanto, K. D. (2018). Dasar-dasar latihan beban. UNY Press.

Prasetyo, Y., \& Nasrulloh, A. (2017). Weight training with pyramid systems to increase the leg and back muscular strength, grip strength, pull, and push strength. Man in India.

Sucipto, E., \& Widiyanto, W. (2016). Pengaruh latihan beban dan kekuatan otot terhadap hypertrophy otot dan ketebalan lemak. Jurnal Keolahragaan. https://doi.org/10.21831/jk.v4i1.8131

Suharjana, S. (2013). Kebugaran jasmani. Jogja Global Media.

Sukamti, E. R., Zein, M. I., \& Budiarti, R. (2016). Profil kebugaran jasmani dan status kesehatan instruktur senam aerobik di Yogyakarta. Jorpres (Jurnal Olahraga Prestasi), 12(2). https://doi.org/10.21831/jorpres.v12i2.11875

Vanagosi, K. D. (2014). TRX untuk cabang olahraga panahan pelajar. Universitas Negeri Jakarta.

Vanagosi, K. D. (2015). Analisis kinesiologi teknik cabang olahraga panahan. Jurnal Pendidikan Kesehatan Rekreasi, 1(1), 70-75. https://ojs.ikippgribali.ac.id/index.php/jpkr/article/view/10

Wibowo, S., \& Fathir, L. W. (2017). Effect of total body weight resistance exercise (TRX) on arms muscle power. The 4th International Conference on Physical Education, Sport and Health (Ismina) and Workshop: Enhancing Sport, Physical Activity, And Health Promotion for a Better Quality of Life, 735-743.

Winters-Stone, K. M., Dobek, J., Bennett, J. A., Nail, L. M., Leo, M. C., \& Schwartz, A. (2012). The effect of resistance training on muscle strength and physical function in older, postmenopausal breast cancer survivors: A randomized controlled trial. Journal of Cancer Survivorship. https://doi.org/10.1007/s11764-011-0210-x 